Intersections

Canadian Journal of Music

Revue canadienne de musique
Intersections CANADAN TOURAA OP NUSIC

\title{
James Harley. 2015. Iannis Xenakis: Kraanerg. Landmarks in Music since 1950 Series. Burlington, VT: Ashgate. 153 pp. ISBN: 978-1-4094-2331-7
}

\section{Martin Iddon}

Volume 35, numéro 1, 2015

URI : https://id.erudit.org/iderudit/1038953ar

DOI : https://doi.org/10.7202/1038953ar

Aller au sommaire du numéro

Éditeur(s)

Canadian University Music Society / Société de musique des universités canadiennes

ISSN

1911-0146 (imprimé)

1918-512X (numérique)

Découvrir la revue

Citer ce compte rendu

Iddon, M. (2015). Compte rendu de [James Harley. 2015. Iannis Xenakis: Kraanerg. Landmarks in Music since 1950 Series. Burlington, VT: Ashgate. 153 pp. ISBN: 978-1-4094-2331-7]. Intersections, 35(1), 177-181.

https://doi.org/10.7202/1038953ar

Copyright @ Canadian University Music Society / Société de musique des universités canadiennes, 2016
Ce document est protégé par la loi sur le droit d'auteur. L'utilisation des services d'Érudit (y compris la reproduction) est assujettie à sa politique d'utilisation que vous pouvez consulter en ligne.

https://apropos.erudit.org/fr/usagers/politique-dutilisation/ 
of Verdi's Attila, premiered 2010 by Riccardo Muti in his debut at the Metropolitan Opera, and Rossini's Zelmira, premiered 2009 by Robert Abbado at the Rossini Opera Festival in Pesaro.

James Harley. 2015. Iannis Xenakis: Kraanerg. Landmarks in Music since 1950 Series. Burlington, VT: Ashgate. 153 pp. ISBN: 978-1-4094-2331-7.

This is the first English-language volume, to my knowledge, devoted to the examination of a single Xenakis piece. Kraanerg-a composite word made up of two other Greek words: 'kraan' (to accomplish or perfect) and 'erg' (energy or work) - seems ideally suited for this purpose: it is the longest piece Xenakis wrote, lasting some 75 minutes and integrating both acoustic instruments with electronics and music with choreography and, by extension, relatively complex staging. I should also, perhaps, confess that it happens to be my own favourite Xenakis piece, even though it remains one I have only experienced in recorded form. That my enthusiasm for Kraanerg (and Harley's too) was not mirrored

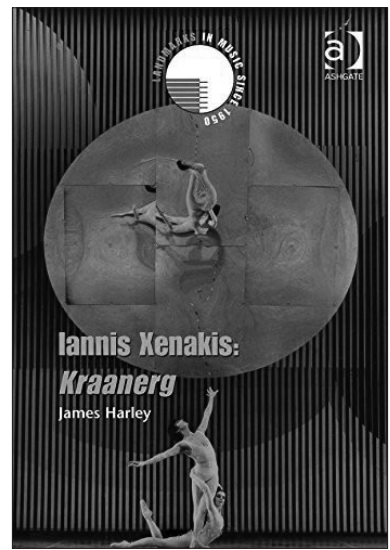
by Xenakis's own relationship with the piece makes this simultaneously a more exciting and more intriguing publication. Though it is a relatively slim volume-125 pages, once the bibliography is excluded-it has been a long time in gestation, the underpinning research going back to the mid-199os and perhaps earlier. Given Kraanerg's scale, and the dense network of media it deploys, Harley's task in covering it in so few pages is a difficult one, not least since the volume seems implicitly to set for itself the goal of using Kraanerg to introduce those (more or less) unfamiliar with Xenakis to his output while still providing sufficient depth to engage with the rich tradition, especially more latterly, of Xenakis scholarship in the writings of, amongst others, Benoît Gibson, Sharon Kanach, and Makis Solomos. The tension between these two poles seems to become periodically tangible within the volume and is not, to my mind, ever fully resolved: some of the volume is too simple for the expert, but too dense for the beginner. But these moments are relatively unusual; for the most part, Harley manages to steer precisely the perilous course between these two extremes with remarkable adroitness, such that there is matter here to engage a wide range of audiences.

Aside from a very brief introduction and nearly as terse an epilogue, the volume comprises six chapters. The first two essentially provide background, biographical and compositional, while the following four are devoted in succession to an historical examination of how Kraanerg came about, an analysis of the piece (at 50 pages, very much the heart of the book), an account of the 
reception of its premiere performances, and a discussion of its later performance history.

The biography summarises the more-or-less well-known facts of Xenakis's life: the balances between his childhood brilliance as both scholar and athlete, between his enthusiasm for science and for the classics (and for science fiction too), between the contemporary and the ancient; his very moderate studies in music as compared with his training as a civil engineer; his service in the Greek Resistance against first the Axis forces, then the British; the facial scarring and loss of an eye as a result of a mortar attack during this period; his flight from Greece to France to avoid internment as a Communist or Resistance fighter, where he became a member of Le Corbusier's atelier, taking a leading role in the design and construction of the Philips Pavilion, while simultaneously becoming a member of Messiaen's class at the Paris Conservatoire, where the older composer encouraged him to write music from what he did know-Greek culture (ancient and modern), mathematics, and architecturerather than try to 'correct' the lacunae in his knowledge of traditional harmony and counterpoint; and so on. Harley challenges little of the well-known account-the portrait of Xenakis here is still broadly a self-portrait-but covers the ground extremely well in such condensed form (and his gentle note that Xenakis should not simply be taken as yet another representative of the postwar 'heroic outsider' trope-that this is a question of perception as well as of the 'truth' of Xenakis's biography_is well made and well taken (4).

The second chapter arguably attempts the impossible: to give an account of Xenakis's underlying compositional techniques up to the point of composing Kraanerg in sixteen pages without overwhelming the reader. Perhaps unsurprisingly, it is the broad sweep which is most compelling and useful: Harley stresses the role of intuition in setting up the initial conditions for a piece; that in Xenakis's music the core materials-'sonic entities'-involve pitch bundled together with other musical parameters; that these materials are, within formal segments, manipulated stochastically (which is to say according to a statistical distribution which is nevertheless unpredictable in local detail) without (necessarily) any 'organic' relationship to large-scale formal decisions. Inevitably, the generality maps imperfectly onto individual pieces, but the broad sweep usefully helps the reader listen for the sorts of rich, local detail alongside quite a strict approach to formal division. The description of sieves and groups is, to my mind, less successful. The general thought-that group theory enables Xenakis to plot trajectories through the larger-scale shaping of parameters, from formal section to formal section, while sieves provide a method for making those trajectories have elements of consistency without predictability - should be enough to help a reader through the specific matter in the present volume. Nevertheless, the explanation of Xenakis's approach to group theory is arguably too brief, the provision of Xenakis's own diagram of rotations of a tetrahedron within a cube (27) hardly more helpful here than in Formalized Music, while the description of sieves is complicated by an error in table 2.1 (25) where, in each of the complements shown, a number which is not part of the repeating pattern is indicated. The pen portraits of Xenakis's 
relationships to dance and to architecture too are suggestive of the importance of both space and motion to Xenakis throughout the 196os and later and set up the territory for the following chapter, which runs briskly through the commissioning procedures and developments of collaborations, with Roland Petit as choreographer for the National Ballet of Canada, Lukas Foss as conductor for the piece, and Victor Vasarely as designer. It may have been Petit who proposed Xenakis as the composer of a ballet for the opening of Ottawa's National Arts Centre (NAC), while the latter two seem to have been proposed by Xenakis once he was involved with the NAC opening gala. The seemingly intuitive or providential relationships between Xenakis's music and the broader context for Kraanerg - from Petit's stated desire to choreograph "as a sculptor makes a sculpture" (42) to the geometric, brutalist architecture of the commissioning venue and the black and white ribbons of Vasarely's op art staging-give a strong, but in no way didactic frame in which for the reader to encounter the sonic world of the piece.

Harley's analysis chapter shows the sorts of materials Xenakis began with when planning Kraanerg, the way in which other pieces (especially Akrata, Polytope de Montréal, and Nomos alpha) informed those materials, and that the score appears in a literal sense to have been cut and pasted together from other materials (and that, in the near absence of sketches it is not clear from where these materials come, even though it is clear that the recording of string and wind materials used in the tape part do not derive from the same source.). Moreover, Harley outlines the way in which Xenakis works in large-scale formal blocks, like a sort of mosaic, and shows, through a variety of tabular formats, the ways in which these blocks of material-tape and ensemble-relate to one another. Yet it seems to me that under the guise of 'analysis', the chapter does something which is more engaging, more insightful, and, indeed, more useful. In its closing twenty pages - rather than explain how the piece 'functions' or how it is built-it suggests what I read as listening strategies, from the perspective of an expert who knows the score intimately. Much of the insight Harley offers into both formal structure and small-scale detail, as well as the way in which the live ensemble interacts with and is juxtaposed against the pre-recorded material, could be educed from a relatively slow working through of the piece with the score. Yet what seems in part to be a sort of writing out of Harley's own listening makes sense and virtue of the presence of the CD which accompanies the book, providing, as it were, a local's map of the territory.

The final two major chapters examine the piece's immediate reception and later performance history. Initial reactions were hardly positive, even though many of the issues were outside Xenakis's hands: the NAC's brutalism was not universally welcomed and-notwithstanding the centrality of Canadian artists and directors, including Michel Tremblay, André Bassard, Jack Winter, and Gabriel Charpentier, to most of the rest of the programme to celebrate its opening-many felt that this major full-length ballet commission ought to have been handed to a Canadian composer and choreographer team. Indeed, the press response Harley provides suggests that, uncompromising and unrelenting though Xenakis's score is, most were favourably impressed by 
its compelling abstract structures. They were not so kind to Petit's choreography, which appeared to be essentially unrelated to the score (and without the productive dissonance that, for instance, Merce Cunningham might have brought) and old fashioned in the light of the more 'authentic' modernism of Xenakis and Vasarely. Boosey \& Hawkes had negotiated with the National Ballet of Canada that it would undertake 50 performances over two years, with an international tour, but there would ultimately be only 19. Perhaps, Harley suggests, it was the failure of the score as a ballet that led to Xenakis's later reluctance to speak much of Kraanerg at all, though, as Harley enumerates later performances, as well multiple concert performances-especially from the mid-199os onwards and five commercial recordings - the Sydney Dance Company managed daily performances between 4 and 26 November 1977 under the much more successful choreography of Graeme Murphy, while in 2004 there were four Berlin performances in January 2004 with Sasha Waltz's choreography projected on multiple video screens, the project directed by Daniel Kötter. From an assuredly inauspicious start, Harley establishes that Kraanerg has been performed at least 65 times, which, for a work of this scale, seems to suggest that, on one level at least, it has proved much more successful than the composer himself believed.

Despite the occasional tensions highlighted above, the volume seems to me to be unambiguously successful. It balances a wide range of competing avenues of discussion in ways which enable comprehensive coverage of the piece without tendentiousness, and terseness without superficiality. If putting the piece thoroughly into the 'proper' context of how Xenakis's compositional practice functions more broadly is impossible on this short scale, Harley achieves something which seems to me to be more useful and more impressive in steering a reader comprehensibly through a dense piece written on a mammoth scale without the demand that that reader wholly comes to terms with this denser context. It seems to me both that Harley compellingly makes the case that the best evidence for the value and importance of what Xenakis has done lies in the experience of the piece itself, and that he puts his readership both into the position that they can immediately do that and, perhaps, then start to make the steps toward that more complex world of sieves, groups, and stochastics that will enrich the experience yet further.

MARTIN IDDON

\section{BIOGRAPHY}

Martin Iddon is a musicologist and composer who studies post-war music in Germany and the USA, and the author of New Music at Darmstadt: Nono, Stockhausen, Cage, and Boulez, and John Cage and David Tudor: Correspondence on Interpretation and Performance (both Cambridge University Press). He has also published on musical modernism, experimental music, and musical aesthetics, among other topics, for 
journals including Contemporary Music Review, Performance Research, and Musical Quarterly.

Gordon Mumma. 2015. Cybersonic Arts: Adventures in American New Music. Edited with commentary by Michelle Fillion. Urbana: University of Illinois Press. 376 pp. ISBN 978-0-252-03943-0.

Cybersonic Arts: Adventures in American New Music, a collection of essays by Gordon Mumma, presents a compelling history of American experimental music from the perspective of one of its most distinguished participants and astute observers. Possessing the aesthetic sensibilities of an artist, the applied knowledge of a computer scientist, and the communication skills of an attentive journalist, Mumma provides first-hand accounts of historic musical events from the 1960s and 1970s, details the technical configurations of electronic media in numerous productions, and analyzes dozens of compositions that now hold established positions in the canon of experimental music. Perhaps most

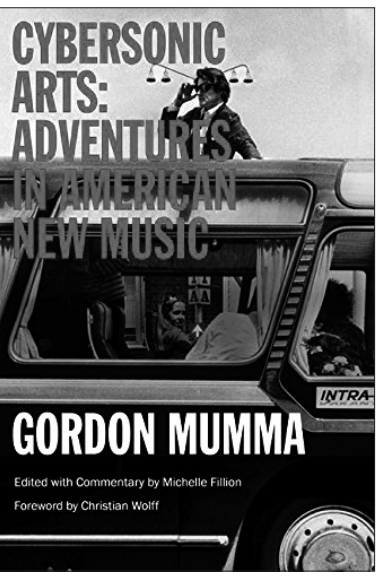
importantly, his essays reflect a profound respect for his colleagues by recognizing music and the arts as a collaborative practice, a creative means of forming and sustaining a vibrant community.

Mumma's writings overwhelmingly dispel the romantic and grossly misleading myth of the experimental artist as an isolated figure. Indeed, he has thrived on collaboration, as is evidenced by his well-known association with such organizations as the ONCE Group, the Sonic Arts Union, and the Merce Cunningham Dance Company, with whom he developed many of his most celebrated projects. Also, as a veteran composer and performer of live-electronic music, Mumma consistently affirms the human element in technology by highlighting the aesthetic and social implications of people interacting with electronics. The idea of collaboration has been so fundamental to his artistic process that he famously adopted the term cybersonics to refer to "a situation in which the electronic processing of sound activities is determined (or influenced) by the interactions of the sounds with themselves-that interaction itself being 'collaborative"' (39-40).

For over fifty years, Mumma regularly documented his collaborative experiences in journals, essays, and photographs, which form the basis of the articles in this collection. Expertly edited by Michelle Fillion in consultation with Mumma, this compilation of thirty-seven essays is organized into seven sections carrying themes variously defined by chronology, geography, ensemble, and individual. Although many of the articles have been drawn from preexisting publications, several of the pieces have been out of print, and almost 